\title{
INFORMED DESIGN DECISION-MAKING: FROM DIGITAL ANALYSIS TO URBAN DESIGN
}

TOMADA DE DECISÃO INFORMADA EM PROJETO: DA ANÁLISE DIGITAL AO DESENHO URBANO

\author{
Camilla Pezzica', João Ventura Lopes², Alexandra Claudia Rebelo Paio²
}

ABSTRACT: This study describes a new approach to explore the design of public open spaces based on a multidimensional analysis useful to inform decision-making and fosterthe development of evidence-based architectural solutions. It presents an overview of the most relevant design variables and their constraints, providing, in this way, valuable information for the elaboration of a more sustainable urban design, considerate of the local socio-cultural values. This research aims at providing holistic guidance for the development of better design proposals in contemporary urban environments. More specifically, it seeks to synchronously characterize urban spaces at a multi-scale and multidimensional level, both quantitatively and qualitatively, by collecting contributions from Space Syntax Theory, Public Life Studies, Building Science and Environmental/Comfort Analysis in public open spaces. Many advanced digital tools are used for data management purposes and to generate and test iteratively different design proposals. The proposed methodology is based on a range of tests and analyses performed in the process of developing a new experimental project for Largo da Graça, an urban square located in Lisbon's historic centre, which allowed the testing of different design solutions. This experiment generated a digital workflow for the design of the urban square, in which are registered all the steps undertaken to solve the many design problems identified by considering the efficiency targets (centrality, connectivity, enclosure, thermal comfort, security, social equity and interaction). The process comprises a sequence of comparative design reviews and records the choices made when dealing with latent information underlying changing conditions in the use of public space and the programmatic malleability of the Portuguese plaza. The description of the adopted design strategy and the examples extracted from the workflow are used to illustrate the practical approach of the proposed methodology. Ultimately, this study seeks to show how tightening the link between applied research and sustainable urban design can effectively support the design and planning of better public open spaces.

KEYWORDS: Design Methods; Public Space Design; Parametric Architecture; Multidimensional Analysis; Space Syntax.

RESUMO: Este artigo descreve uma nova abordagem ao desenho do espaço público aberto, baseada numa análise multidimensional orientada para a tomada de decisão e para o desenvolvimento de soluções arquitetônicas assentes em evidências. Apresenta uma visão geral das variáveis mais relevantes de projeto e suas restrições, fornecendo assim informações úteis para o desenvolvimento de um desenho urbano mais sustentável, que considera os valores sociais e culturais locais. Este trabalho propõe fornecer uma ferramenta de orientação holística para o desenvolvimento de melhores propostas de projeto em ambientes urbanos contemporâneos; mais especificamente, visa caracterizar de forma síncrona os espaços urbanos através de análises multiescala e multidimensional, quantitativas e qualitativas, incorporando as contribuições da sintaxe espacial, dos estudos de vida pública, da ciência da construção e da análise ambiental/conforto em espaços públicos abertos. Várias ferramentas digitais avançadas são utilizadas para gerir os dados, gerar e testar iterativamente as diferentes propostas do projeto. A metodologia proposta se baseia em diversos testes e análises executados no processo de desenvolvimento de um novo projeto experimental desenvolvido para o Largo da Graça, uma praça urbana localizada no centro histórico de Lisboa que permitiu o teste de diferentes tipos de propostas. Este experimento gerou uma estrutura processual digital para o desenho urbano da praça, no qual se registaram todas as etapas relativas à resolução de vários problemas de projeto, incluindo os objetivos de eficiência (centralidade, conectividade, compacidade,

\section{How to cite this article:}

PEZZICA, C.; LOPES, J. V.; PAIO, A. C. R. Tomada de decisão informada em projeto: da análise digital ao desenho urbano: uma abordagem contemporânea à reabilitação do espaço público aberto. Gestão e Tecnologia de Projetos, São Carlos, v. 12, n. 3, p. 9-26 2017. http://dx.doi.org/10.11606/gtp.v12i3.133936

Fonte de financiamento:

The first author is supported in this study by a scholarship granted by the University of Pisa, Italy, in 2015. The second author is supported by the FCT grant SFRH/ BD/95148/2013. The authors acknowledge the support of the Municipality of Lisbon for the access to official carthographic and documentary data

Conflito de interesse:

Declaram não haver

Submetido em: 24/06/2017 Aceito em: 30/08/2017 
conforto térmico, segurança, igualdade e interação). O processo abarca uma sequência de propostas testadas e comparadas, bem como as escolhas feitas em relação às informações latentes, subjacentes às condições de mudança no uso do espaço público e à adaptabilidade programática da praça portuguesa. A estratégia de projeto adotada e os exemplos extraídos da estrutura processual digital são usados para ilustrar a abordagem prática da metodologia proposta, pretendendo assim demonstrar como o vínculo entre investigação aplicada e desenho urbano sustentável pode ser o adequado para o planejamento e o desenvolvimento de melhores soluções de espaço público.

PALAVRAS-CHAVE: Métodos de Projeto; Design do Espaço Público; Modelagem Paramétrica; Análise Multidimensional; Sintaxe Espacial.

\section{INTRODUCTION}

Urban design redevelopment projects are currently facing the challenge of creating sustainable solutions that meet the needs of local residents. However, according to Nisha and Nelson (2012), design-led initiatives have often failed their objectives because of an excess of subjectivity in the design approach, sometimes leading to gentrification problems and aggressive city re-branding, contributing to socio-economic polarisation. Consequently, there is an urgent need for alternative and more objective design methodologies able to support designers in the creation of more equitable and inclusive urban environments. The success and the sustainability of urban development projects depend on three main factors: economy, environment, and society, which are mutually dependent. In particular, social and cultural sustainability in cities is contingent upon a design of the physical environment that accounts for the identity of the place and the social habits of its users. To better deal with all these issues, this study adopts a tailored and properly integrated methodology of urban analysis and design. According to many authors (BENEDIKT, 1979; HILLIER, 1996; MADANIPOUR, 1999), people's behaviour is directly influenced by the urban morphology, which poses the conditions for the social construction of space. Therefore, designing physical urban elements that consider the local context and respond to community needs and climate issues at the same time could be an effective way for developing sustainable urban transformation projects. Ultimately, this article builds on previous work to build a framework to support evidence-based design decision-making for the creation of successful public open spaces.

Public Open Spaces are commonly acknowledged as key nodes in urban network structures and as an essential part of everyday social reality. Among them, the plaza shows the most exceptional features, displaying a unique combination of characteristics: (i) positive void shape purposely designed and defined by the surrounding vertical planes; (ii) symbolic/ aesthetic importance; (ii) social value reinforced by the integration of politic and cultural activities together with communal practices of different age groups. In relation to the urban system as a whole, the origins of the diverse characterizing traits of a square are both global and local, which requires the adoption of a multi-scale and multidimensional approach. Since we can no longer approach such complex design problems without prior or parallel qualitative and quantitative analysis and the use of new technologies, a computational design research is applied as a response to variations in performing criteria (ARCHITECTURAL DESIGN, 2015). The general objectives of this work are part of an ongoing research project (PEZZICA; PAIO; LOPES, 2016; LOPES et al., 2017) whose final goals are both to create a new method to characterize and classify public open spaces able to gather descriptive and structural approaches to the study of urban form in a single process, and to foster the generation of high-quality proposals in urban design practice. 
In order to prepare the ground for the research, a comprehensive literature review on the study of squares has been undertaken, including relevant studies on thermal comfort analysis for outdoors and data mining, which resulted in knowledge transfer from different disciplines for the development of the presented inductive approach to urban analysis and design. The new methodology has then been implemented and tested in a suitable case study: Largo da Graça, a Portuguese square located in Lisbon's historic centre. This experiment provided a practical example of how evaluation phases may interweave with design phases, thus influencing the generation and modification of the design proposals. Specifically, this applied research gives some insights on the possibilities of undertaking design changes when Space Syntax and Public Life Studies are a part of the decision-making process. The workflow is illustrated through the description of different design stages and of factors, indicators and multimodal ways of representing public open space, which have helped the design process. To sum up, this study presents a new way to approach the analysis, planning and design of public open spaces which invites the designer to perform a comprehensive synchronic and diachronic study of the design space. The proposed method provides insights on the socio-spatial consequences of the different design choices and thus helps to overcome the issue of subjectivity in contemporary redevelopment projects as well as the lack of systematic post-occupancy reviews of urban design interventions. Ultimately, it helps architects to learn more about design problems and also to explore further architectural ideas and understand the possible effects of their proposals (DURSUN, 2007).

This study has four sections: the first one introduces the state of the art on square analysis and design, offering an overview on the existing techniques of public life studies; the second one explains the proposed approach to the development of urban design; the third one illustrates the implementation of the method in the selected case study. Finally, the fourth section presents a critical discussion of the results and suggests further lines of research.

\section{Theoretical framework: public open spaces, spatial analysis and public life studies}

Urban morphology seeks to understand the characterizing urban gene of a given settlement together with its natural growth pattern by studying its spatial grammar and the diachronic transformation of its elements. It is widely accepted that the development of meaningful typo-morphological descriptions of urban spaces is essential for understanding the qualities trapped in urban structures and that classification has always had fundamental role in the structuring of knowledge on cities. In particular, public open spaces have a strong morphological individuality, easy to recognise and generally resilient to urban transformations. Even if we consider only modern authors in this field, we can see that the problem of the classification of public open spaces - and among them, the square - is recurring. The approaches tend to focus on squares' geometrical or functional properties and run from the more intuitive to the more analytical (CHOAY, 1973; CLOQUET, 1898; GUIDONI, 1989; KRIER, 1979; SITTE, 1953; ZUCKER, 1959). These studies concentrate on the relationship of the square with the exceptional buildings that surround it and on the social and political reasons of its creation. However, these kinds of classifications hardly apply to contemporary public open spaces, which defeat abstract generalizations. Nonetheless, the analysis of the spatial relations that exist between a square and its surrounding context may still be useful, especially if we add some quantitative information to the mainly qualitative descriptions of the past. A significant step towards the achievement of quantitative morphological descriptions was done in the 1980s, when Bill Hillier 
developed the Space Syntax theory (HILLIER; HANSON, 1984). In fact, the Space Syntax community promoted the development of many analytical techniques able to capture the configurational properties of urban spaces at various scales and resolutions. Several authors (CUTINI, 2001; HILLIER et al., 1993) demonstrated the existence of a high correlation between syntactic properties and some urban phenomena. Furthermore, by studying the topological nature of space rather than its built form or shape, the Space Syntax generates non-arbitrary and reproducible spatial descriptions and representations and enables the direct comparison between different systems. The Space Syntax community has also recently provided a significant contribution to the study of squares (CAN et al., 2013; HEITOR et al., 1999; KOOHSARI et al., 2014; KUBAT et al., 2015) and the configurational analysis proved to be a valuable support tool to the design of many successful public spaces (KARIMI, 2012), such as Trafalgar Square and Nottingham Old Market Square (SPACE SYNTAX, 2004).

This study builds on these works and on the research of authors such as Cutini (2003) and Guerreiro et al. (2014), who have tried to identify the configurational conditions for squares to function as meeting and interaction spaces. The work of the former refers to the studies of Sitte (1953) to build the formula for the calculation of the interaction index, which discloses the hierarchy of squares in cities, whereas the latter studies the pedestrian network together with public life patterns (WHYTE, 2001) in an integrated way. Their research results show that it should be possible to build more comprehensive knowledge on squares as well as create composite models of design evaluation, by integrating the configurational analysis with other data. Specifically, field observations of configuration-related behaviours seem useful means to test configurational analysis models by validating the reliability of the outputs and their predictive capacities (ASRIANA; INDRAPRASTHA, 2016).

During field observations, counting, mapping and tracking pedestrian activity as well as using time-lapse photography can be highly valuable sources of knowledge. These techniques belong to field of public life studies, which investigates urbanity through the study of public space usage patterns. This research field only had a considerable development in the 1960s, when firstly emerged the urgency to rethink the roles of the public space from a people-centric perspective, as a response to the modernist paradigm. The work of authors such as Cullen (1961), Jacobs (1961) and Lynch (1960) falls into this tendency, which became increasingly systematic with the contributions of Gehl (2011) and Whyte (2001). Action research, area studies and behavioural mapping are just some of the techniques to study public life, which combined with Space Syntax analysis can effectively inform design decisions. Furthermore, environmental and thermal comfort analyses may help to explain some observed anomalies and seasonal phenomena and thus underpin the correct interpretation of field data (GHEL; SVARRE, 2013).

To conclude, urban design requires new effective responses to enforce the shift from a design-led product to a bottom-up process approach. To achieve this, it seems a good strategy to focus on the development of a multidimensional and interdisciplinary "learning by doing" method of performance-oriented iterative analysis and design. Therefore, this study explores the contributions of Space Syntax theory, Public Life Studies and Environmental Analysis to the design of a good public space able to make the city work better (MICHEL, 2007).

\section{A multi-scale and multidimensional methodology for the study of public spaces}

An effective framework for supporting the design of successful public open spaces must consider the non-procedural nature of the design process 
and allow for a certain freedom in deciding the sequence of analysis and design. In fact, the creative process is not procedural and normally has no definite direction of flow from design activity to its evaluation. Moreover, architects consolidate or re-define their ideas by generating and reviewing different design proposals. They learn about design problems through the development and the critical assessment of solutions, rather than through a separate analysis of the problem itself (LAWSON, 2003). Therefore, this study seeks to support designers' decision-making by proposing a hands-on, open-ended approach to analysis and design (Figure 1).

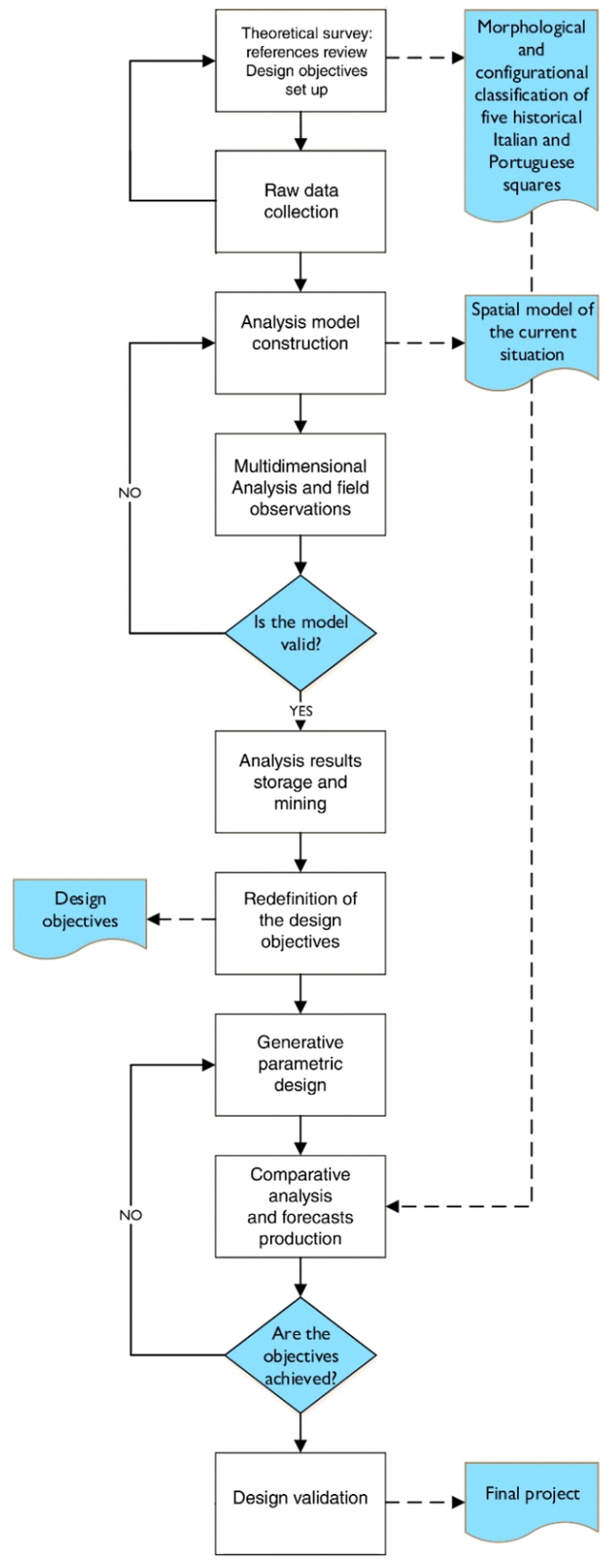

Figure 1: Flowchart of the proposed methodology

Source: the authors

The design development process encompasses the following five stages: 


\section{Stage 1: definition of the significant attributes}

In the first stage, the designer surveys relevant theories and methods and collects the analysis tools. After firming the concepts and the analysis criteria a significant set of formal and spatial (metric, geometric and topological-syntactic), environmental and perceptual-cognitive attributes is defined. In this study, the analysis was restricted to a set of ten attributes divided into four main themes: 1 . Accessibility and connectivity, through Visual Graph Analysis (VGA); 2. Urban System, global characteristics of the urban structure where the square is located, through Axial Analysis; 3. Uses and functions; 4. Environmental characteristics.

\section{Stage 2: model construction and data extraction}

In the second stage, the designer creates the 2D and 3D digital models of the city and the square and then processes the computation of some preliminary analyses in a semiautomatic workflow. For the production of the models and the extraction of data, many different software are required: standard CAD tools, Depthmap X (UCL), QGis and Rhino/Grasshopper together with its plugins (e.g. Ladybug and Honeybee by Mostapha Sadeghipour Roudsari; Kangaroo by Daniel Piker; and Space Syntax by Pirouz Nourian). The programming capacity of Grasshopper is particularly useful to develop algorithms for the storage and the post-processing of the information previously extracted, which could be used later on for further data analysis such as data mining (AHU; CAGDAS; SARIYLDIZ, 2011; LOPES at al., 2015).

\section{Stage 3: model validation by direct observations}

In the third stage, the designer studies the square in its actual configuration by field observations. People are counted and their paths are traced on a plan while stationary activities are mapped. These studies allow the designer to ensure the reliability of the analysis model in producing accurate forecasts. This crosscheck should be done by considering the relationships between human behaviour and configurational properties as well as environmental factors.

\section{Stage 4: development of an iterative design process}

In the fourth stage, the designer finally approaches the project adopting a generative design logic, which enables the use of the analysis variables as design-driving parameters as well as project constraints. This approach enables the structuring and systematization of the iterative and interactive process between analysis and design, which is a valuable support for dealing with the experimental and probing nature of the design development process. At this stage, the visual programming interface (VPI) of Rhino/ Grasshopper is extremely useful to visualise and navigate the analysis results, find efficient and appealing design solutions and ensure satisfying configurational characteristics and comfort features to the square.

\section{Stage 5: final design audit and validation test}

In the fifth stage, the designer reviews the final design outcome and numerically evaluates the effectiveness of the proposed project in improving the chosen quality parameters. Predictions on the expected transformations 
in terms of public life can be done at this stage, on a theoretical basis and as a result of two comparative analyses: first between the current situation and the final design and second between the final design and other successful squares (PAIO et al., 2016).

\section{DATA-DRIVEN DESIGN DECISION-MAKING FOR PUBLIC OPEN SPACES}

\section{The case study}

The proposed methodology is implemented and tested in the case study of Largo da Graça, thus providing an exemplifying description of the strategies used to undertake design actions as well as the many assumptions behind each decision and illustrating how analyses can be used as part of setting and assessing design aims.

Largo da Graça, initially known with the name of Largo do Convento da Graça, is located at the top of the slope where the homonym convent lies, in the core of Graça neighbourhood, in Lisbon's historic centre. The surrounding area is mainly residential (urban zone A, consolidated) with a total population of 20,531 and an average dimension of families of 2 people. Apart from the locals, Largo da Graça is frequented by a high number of tourists that arrive with the popular tram 28 to visit the Miradouro da Graça, located near the eastern side of the convent. Largo da Graça has a complex character, reflected by its roughly defined and highly fragmented boundary, its diversified topography and the presence of a number of impactful elements such as high retaining walls, central green areas and a big fountain. It consists of an irregular sequence of sub-areas: one of them is monumental and linked to the convent, while the largest one shows a strong commercial vocation and is surrounded by buildings of lesser architectural interest. The existence of six toponymical inscriptions along an area of intervention of $15,620 \mathrm{~m}^{2}$ proves the complex character of the place. Nonetheless, this area shows a latent potential for liveliness, which the redevelopment project aims at strengthening. Even in urban toponymy the word largo and the Latin largus are used to identify a public space in which the transit function is as important as its functioning as a gathering point, so that sometimes the word largo is used as a synonym for square. Despite lacking the physiognomy and the importance of a formal square, Largo da Graça already performs many of its public functions, being a public open living place, where locals and tourists meet day by day. Making it an inclusive place is therefore crucial, especially if we consider the case of Lisbon, which is currently challenged by the issue of accommodating a growing tourist population in a socially sustainable and equitable way.

\section{Approach to analysis}

This section provides a description of the strategies used to interpret the square's space considering principles, attributes and scientific procedures. The analysis leading concept is the notion of the plaza, which means size, centrality, enclosure, architectural quality and unitary image. These features are strictly dependent upon spatial properties such as visibility, connectedness and accessibility, which relate to the number of people using the streets.

Translated into Space Syntax words, the quality of a square depends on the values of the clustering coefficient, connectivity (or neighbourhood size) and integration indexes, which can be studied separately or combined in the 
Interaction index (CUTINI, 2003). The values of the integration index were retrieved both at a global and at a local level. In the first case, it was useful to understand the global accessibility level of the square to spot the main routes of access from outside the Graça neighbourhood. A segment analysis was therefore processed on a bigger portion of the urban grid of Lisbon and allowed the generation of the radius $n$ integration and choice maps (HILLIER; LIDA, 2005), representing respectively to movement and through movement according to the Space Syntax terminology. From the analysis of the area, Largo da Graça turned out to be a micro centrality with a high potential to be a great public space. Then, the analysis was repeated within a metric radius of 800 metres from the square, which corresponds to the distance that a pedestrian can walk in ten minutes. This allowed us to map the local access points and combine them with the global ones (HILLIER, 2009). Additionally, a $1-\mathrm{m}^{2}$ resolution VGA (TURNER et al., 2001) was processed to visualize the disparities in the values of the relevant syntactic indexes inside the twodimensional space of the square. This analysis was extremely useful, for example, to highlight the areas easier to control and hence, the places of the square where people normally prefer to stay to look at other people as well as the more visually segregated zones. Finally, an agent analysis was processed to generate aggregate models of agents' movement in space (PENN; TURNER, 2001).

Besides visibility conditions, the microclimate - that is, the local climate of a specific site - has a heavy impact on whether people chose to stay in a place or not. In fact, a higher level of environmental quality is required for incrementing stationary activities. Therefore, using Lisbon's weather data (type of extension .EPW), we made a thermal analysis aiming to assure to the square a sufficient level of outdoor comfort during the entire year. Once defined the conditions of no thermal stress when the perceived outdoor temperature is between 9 and 26 degrees Celsius, Ladybug enabled us to determine the total percentage of comfortable hours in Lisbon during the entire year which resulted to be only $47 \%$. Therefore, throughout investigation of this matter was crucial for the purpose of the project. As a result, we created a chart representing the specific comfortable (red) or uncomfortable (blue) thermal conditions of Largo da Graça for each hour of the year. This chart highlighted the extreme condition of discomfort, due to the excessive heat, that occurs from May to October in the central hours of the day, threatening the full enjoyment of the public space during the warmer season. Field visits conducted over a period of eight months (October - June 2016) helped to verify these results and to collect additional information on the social life of Largo da Graça.

To conclude, the analysis model and the obtained results have been validated by means of a number of monthly in situ observations in which the people's behaviour was recorded. Afterwards, the public life maps were overlapped and integrated with notes, relevant numeric data and photographic documentation within a "public life survey journal." The resulting picture appeared in good accordance with the outcomes of the analysis. At this point, the model was considered definitively validated and suitable to be used for testing the various design proposals and thus ready to actively support the design decision-making process (Figure 2).

\section{Approach to design}

The design was developed in three steps:

- The set up, which defines the starting point of the design based on the premises of problem framing and the general design concept; 
- The iterative development, in which main design actions are undertaken, evaluated and acted upon with the help of the analyses and refined with the help of cross-comparisons of design alternatives;

- The performance test, in which the design proposal is tested against other successful examples and against itself, assessing the quality of the project.

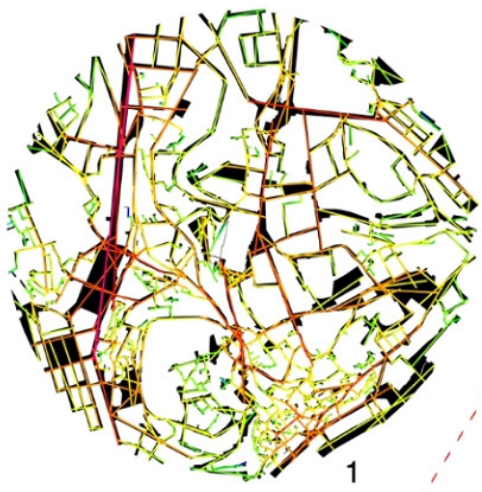

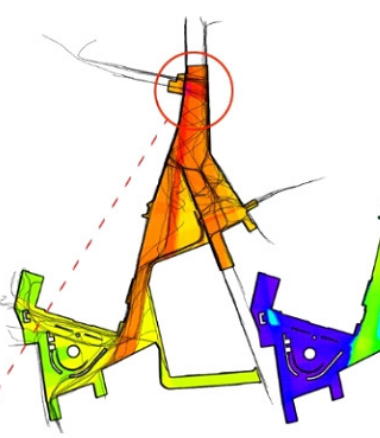

2
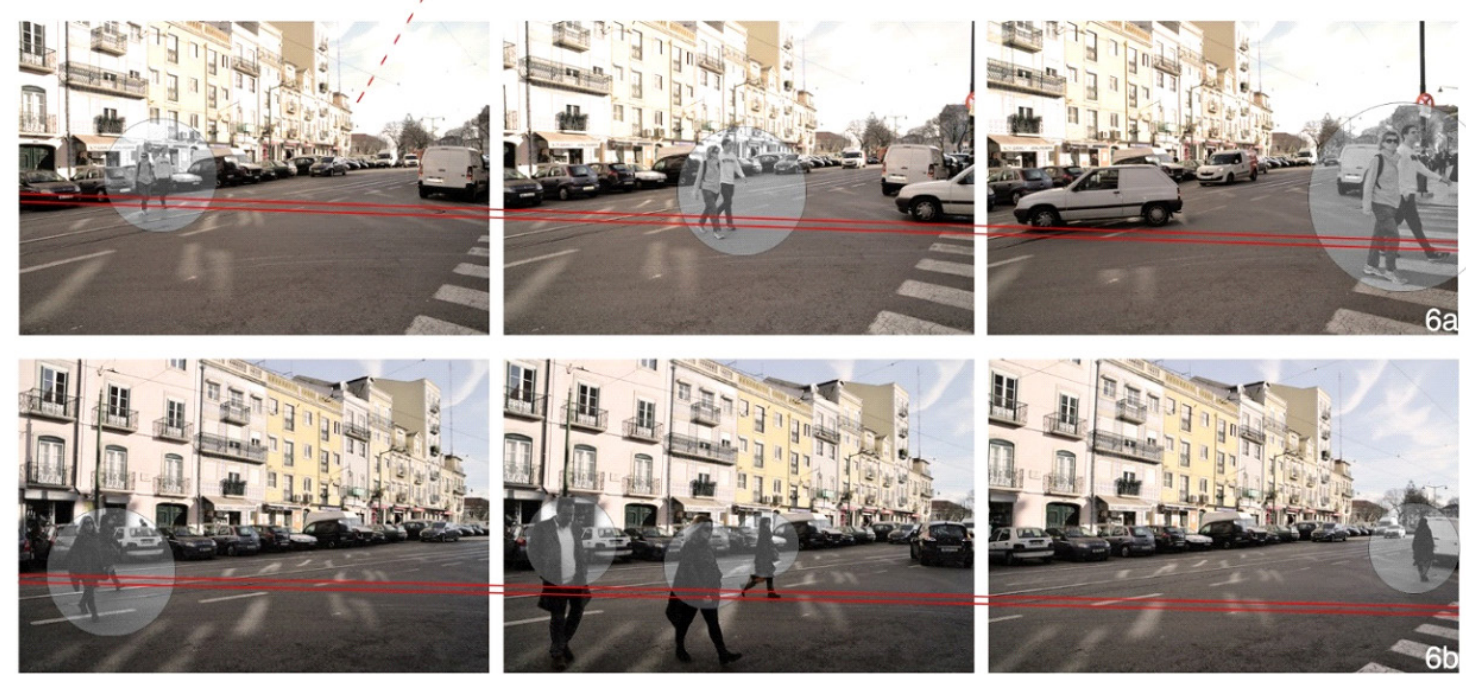

\section{Set up}

The design strategy is built on the principle that only the presence of people coupled with weak or no barriers creates a public space (GHEL, 2011). The project originates from a superimposed hierarchical grid, created to structure, hierarchize and define the square's spaces and built components, their functions and spatial dispositions. The design of the grid is parametric, thus increasing the control over the project and the possibilities of further investigations at various scales (MOTTA, 1999). The geometry and concept of the grid derive from the Portuguese tiles, the azulejos, which are a distinctive architectural trait of Lisbon and in particular of its oldest neighbourhoods. By doing this, the intention is to consider the genius loci and hence link the new project for Largo da Graça to something that recalls its identity and its history, ultimately combining a practical necessity with a local cultural feature. Moreover, the geometries of the patterns used in the design of azulejos have many interesting properties, among which a rigorous
Figure 2: Square

multidimensional analysis. 1. Axial integration r3 (local accessibility map); 2. VGA integration overlaid with people tracking; 3. VGA connectivity; 4. VGA clustering coefficient; 5. Agent analysis; $6 \mathrm{a}$ and $\mathrm{b}$. Timelapse photography of people informal crossing and validation of the configurational analysis through directly surveyed data

Source: the authors 
multilevel hierarchical structure, which enables the same pattern to recur at different levels (Figure 3). This property allows the architect to adapt the resolution of the pattern of the grid to the different scales of interventions concerning the specific design purposes without losing track of the global algorithmic logic. To be able to scale and rotate the adopted pattern as required, we created a parametric definition by using Grasshopper, which allowed a certain degree of flexibility, especially helpful in the first phases of the design process. Starting from the pattern definition, some elements could immediately be derived: a grid of points, three main linear directions and finally an infinite set of possible areas, which have been used as the starting point for the subsequent design.
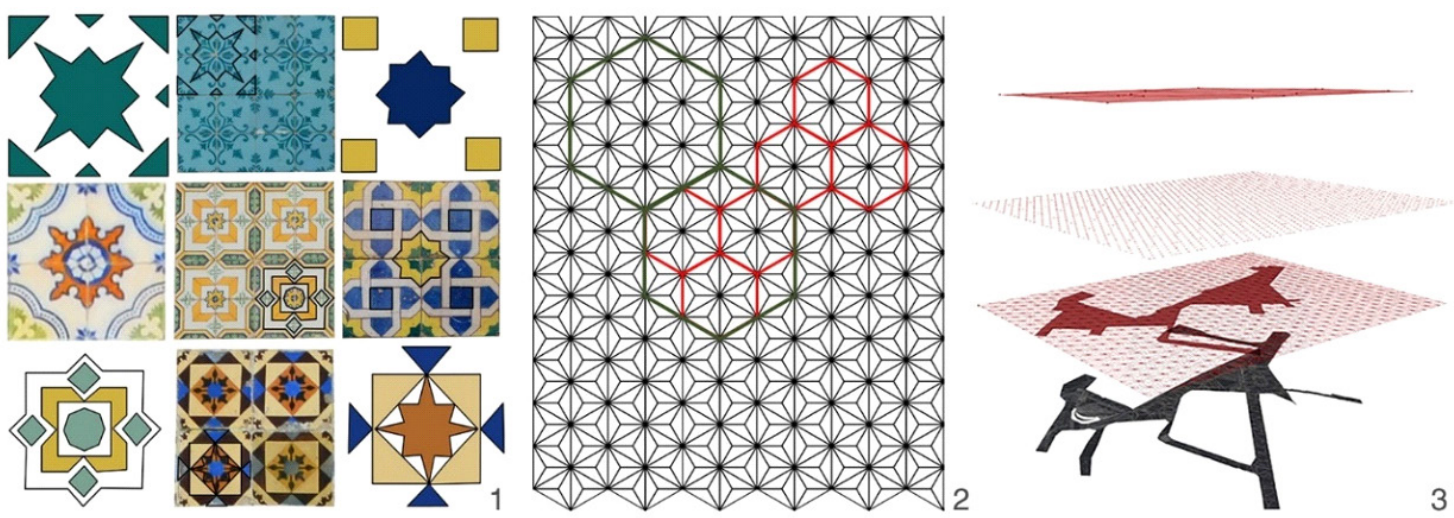

Figure 3: The grid as a designdriving concept. 1. Portuguese azulejos: A kind of glazed coloured tile traditionally used in Spanish and Portuguese buildings as a wainscot or facing; 2. Grid extracted from tiles with its multilevel hierarchical structure; 3 . Superimposition of the pattern over the area of the square

Source: the authors

\section{Iterative development}

The design was iteratively redefined based on the following performancedriven design strategy.

\section{Configuration-related features}

A serious deficiency of the square, which resulted from the VGA and agent analyses, is the virtual absence of movement across the heart of the square, caused by the existing topography and the current disposition of the retaining walls (DALTON, 2003). Consequently, when it comes to the design development, the first step was to break down the visual barriers to facilitate the establishment of visual relations within the square. This led to the development of a new design proposal in which the morphology is rethought in a way that invites people inside the square, giving its shape a smoother appearance as well as a less fragmented configuration. Accordingly, the vertical connections between the different topographic levels of the square were re-designed. In the north part of the square, the 1- to 3-meters height difference in correspondence with the main street was used to build a system of consecutive and connected smaller places for interaction, whose drawing was derived from the grid. Their design originates from the necessity to invite people inside the elevated part of the square. To reach this objective it rigidly follows the Whyte (2001) four steps maximum principle. According to Whyte, "the area where the street and the plaza or open space meet is a key to success or failure" so that "ideally, the transition should be such that it's hard to tell where one ends and the other begins." The new design proposal is developed accordingly and is structured in a way that people in the lower spaces provide the show to the people sitting or walking above. As a result, the orography of the site will somehow resembles an amphitheatre. The new project considers the constraints represented by the doors along the perimeter of the square as 
well as the restrictions regarding heritage buildings. The design proposal was iteratively refined until it was possible to extend the view lines across the entire area occupied by the square. In the end, the elimination of the visual barriers led to a relevant increment of the average value of the $\mathrm{r} 3$ integration index (local accessibility).

\section{Program and materials}

With the aim to physically and functionally connect the square to the surrounding buildings, the new paving was designed according to a simple principle: to adopt different textures for the places to move and for the places to stay, which are otherwise integrated in a unitary system. Special attention was put to create a continuous flooring, which passed along the main axial lines and connected all doors, thus creating a functional and wide pedestrian route-space marked by a resistant and anti-slip material. The remaining areas were subsequently divided into two qualitatively different zones: green spaces, which perform some programmatic functions and host some coherently selected botanic species, and paved areas which represent the places to stay, to seat and to contemplate. The former ones were generally located along the perimeter of the square, while the latter ones occupied the actual core of the plaza. Specifically, the areas to stay have been designed with the aim to invite stationary activities by providing a large and feasible number of places to sit, good visibility conditions and close proximity to the walking paths. All the described spatial and programmatic subdivisions are coherently highlighted by the use of different materials: black basalt for the strolling paths and white limestone for the places to stay, somehow recalling the traditional Portuguese flooring. When it comes to the places to sit, a further effort was done for improving the outdoor thermal comfort conditions during the hot months. Finally, this resulted in the introduction of a temporary lightweight shading system, whose design follows the same generative rules of the entire project.

\section{Outdoor thermal comfort}

Comfort in architecture relates to several aspects of how a space is designed and involves many psychological/perceptual factors, as for example in the case of the perception of security, which is conveyed not only by spatial configurational properties, but also by materials, colours, shapes and visual language. Among other aspects, thermal comfort, which is the satisfaction of the occupants with the surrounding thermal conditions, is essential. As a result, considering the fact that Lisbon is situated in southern Europe, which is also the hottest EU zone, it seemed vital to consider the thermal factor. In fact, good thermal conditions will ensure the possibility for everyone to engage with other occupants of the square during the entire year. Accordingly, as already anticipated, the current heat-related critical issues were solved by including within the design of the plaza a system of removable and adjustable tensioned textile membrane structures, tied to steel cable nets. The canopies, or removable sunscreens, were designed with the idea that they should leave a coherent and recognisable architectural sign all over the square. Their architectural purpose was to cover and connect the different spaces with a unifying element. Additionally, they respond to a functional necessity in a fairly sensitive way since they echo the Mediterranean and Arabic tradition of using textile shading devices to protect people from direct solar exposition. Furthermore, the decision to design this removable lightweight system was based on reasons of economic convenience, ease of assembly and disassembly, flexibility and adaptability as well as suitability of the adopted system to cover large areas without resorting to heavy and invasive structures. To sum up, the design of the 
coverage responds to multiple necessities: First of all to give a unitary image to the square by clearly delimiting its space and secondly, to produce better thermal conditions during the summer, which would allow the people to enjoy more time within the square. Finally, the presence of the shadowing system reinforced the concept of the Arabic structuring pattern. In fact, the canopies were generated by adding a further dimension to the 2D geometry of the base pattern. To test and optimise their design, we used a Ladybug component called "Comfort Shade Benefit Evaluator," which is based on the Shaderade method developed by Seargent, Niemasz and Reinhart (2011), but substitutes Shaderade's energy simulation with an evaluation of heating and temperature degree-days, which are calculated in relation to a balance temperature set at 20 degrees Celsius. This component enabled us to perform the analysis only on a planar grid and then we projected the thermal analysis results onto the shading test surfaces, by following the direction of the average summer solar ray. The process was repeated many times, every time changing the percentage of shading areas to keep and re-calculating the savings. Based on the results, we finally identified an optimal percentage of test surfaces to keep, which resulted in the $38 \%$ of the shading test area. This choice allowed us to guarantee a saving of 5.57 degree-days, which seemed to represent the best trade-off in terms of quality versus cost if we consider that a $100 \%$ coverage would save just 8.92 degree-days. To conclude, the final design of the shading system was the outcome of a form-finding process that aimed to maximize the comfort revenue while minimizing the construction costs. This was evaluated by roughly considering the loads and by calculating the structural sections for each design alternative.

\section{Additional design elements}

After solving the most critical thermal issues, we focused on the other complementary factors that contribute to the improvement of the general level of environmental comfort in the square. The notion of environmental comfort depends on how the architectural-built forms engage with the occupants, who experience the surrounding environment through all of their senses. More specifically, the realisation of a comfortable environment seems to be the result of a process of harmonization among many different environmental factors such as lighting, materiality, sound, and so on. Therefore, some adjustments were made to the design of further components of the square, aiming to improve the interaction between the designed elements and the people engaging with them. As a result of public life field observations, we decided to eliminate all the fences that divided the green and the water from the people. Then, we chose to design the green spaces in a way that they helped to protect the areas at risk left uncovered by the shading system and so that they contributed to frame the wind, thus reducing the wind loads on the membranes where possible. Moreover, in the project trees were placed so that they marked the grid points and acted as visual references in leading the visitors to the centre of Largo da Graça. Additionally, we decided to move the fountain from the centre of the square to a more convenient location where people could sit, and engage in informal conversation somehow protected by the sound of water, which tends to convey a feeling of privacy. Furthermore, a new lighting system was designed according to the natural movement pattern (CHOI et al., 2006), which was firstly calculated on the base of the design model and then adjusted according to the new functional program. This resulted in a nonregular plan and height distribution of the street lamps. The benches were placed where the control index was higher, that is, near the corners. Finally, pedestrians' safety was increased by reducing road sections and by drawing wide sidewalks and zebras in two key spots, where we registered the highest level of informal crossings. 


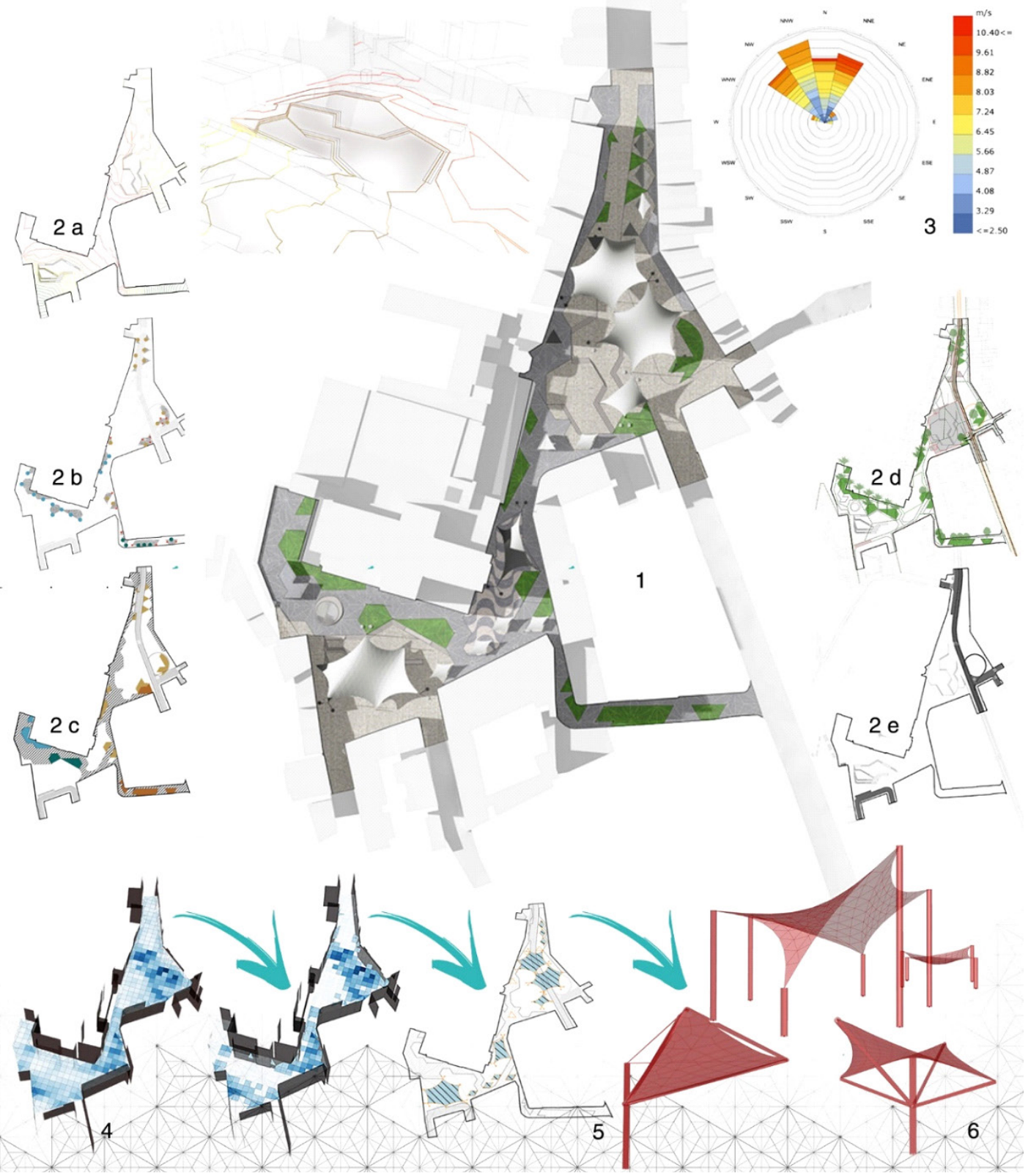

Figure 4: Iterative design development, elements from the design process. 1. Masterplan - summertime;

\section{Performance final test and design validation}

All interventions were organized with the objective to invite the occupation of the square and promote activities that enhance social interaction. The final design outcome was the last of a series of targeted sectorial adjustments made to allow the realization of the programmatic goals (which have been themselves re-adjusted after the analysis). The designed physical space is the hardware that should support the functioning of the general program decided for the plaza - its urbanity. The overall procedure followed a parametric generative logic to responsively adapt to future design changes, allowing a participatory design strategy and getting external specialized contributions at any phase of the design process. In the end, this type of logic seemed to perform well when it came to changing
2. $a|b| c|d| e$. Layers of the developed design: (a) newly designed orography, (b) plant types, (c) pedestrian paths and linear design elements, $(d)$ greenery and parking areas, (e) new viability design; 3 . Wind speed; 4. Thermal Outdoor Comfort Analysis and shading area optimisation; 5. Canopy design and distribution; 6 . Tensile structures 3D geometry generation (Kangaroo)

Source: the authors 
Figure 5: Comparative configurational analysis ( $B=$ before and $A=$ after $) .1$. VGA integration (accessibility); 2. VGA connectivity; 3. VGA clustering coefficient; 4. Agent analysis (gate count); 5. 3D view of the square: before and after

Source: the authors needs, supporting interactive design decision-making and structuring the space of the square. The ultimate test of the design proposal helped assessing the quality of the final project and enabled a comparative ranking of the before and after configurations. To do this, a conclusive VGA test was made considering the final spatial layout (Figure 4). As highlighted by the results, the level of local accessibility and centrality increased along with the values of the connectivity index and those of the clustering coefficient, which, combined, resulted in an increment of $28 \%$ of the interaction index value. There were also tangible improvements regarding the visual control index: the controllable area expanded towards the central spaces of the square instead of being bounded at the corners. This was interpreted as a centralization of the stationary activities, which we believe to be the key for achieving an active occupation of the entire square's area. Another test was done using Space Syntax agent analysis, which generated a forecast on the patterns of movement of people in the newly designed space. The result of this analysis proved that the final design proposal will lead more agents inside the square and to its central areas as well (Figure 5).
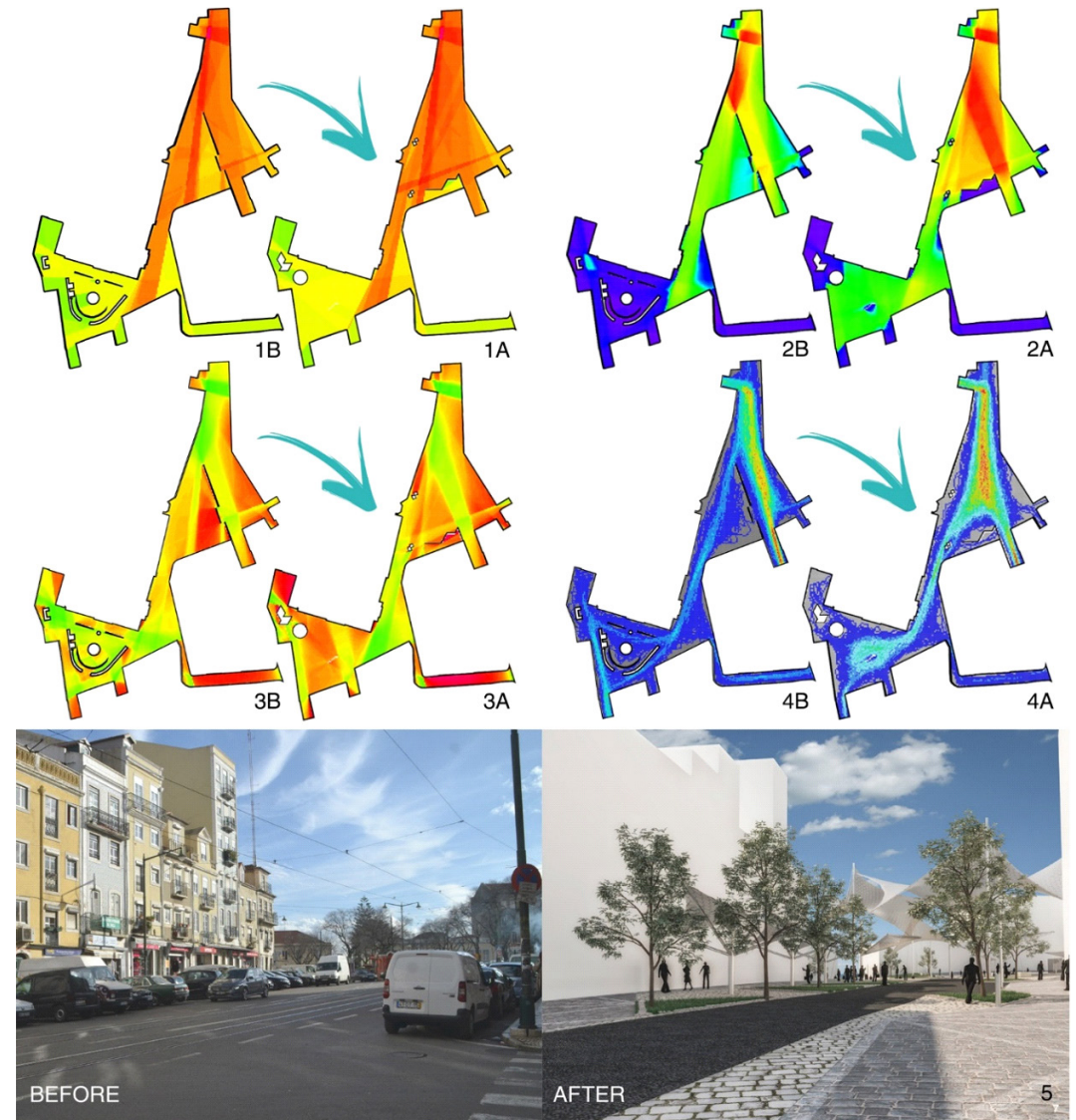

\section{CONCLUSION AND DISCUSSION}

This study presented an experimental applied investigation of the potential for Space Syntax, Environmental analysis and Public life studies to contribute to the better understanding of squares for urban transformation purposes. The exploration has been assisted by the consistency and extent of the available data for Largo da Graça which fed the multidimensional analysis, which in turn provided useful guidance in the decision-making process that led to the final design output (Figure 5). The most valuable aspect of the methodology seemed to be its potential to be used as a part of an 
open-ended and adaptable design and planning strategy, which potentially extends to other urban regeneration projects. The diachronic studies done as a complementary part of the process have helped to define the design objectives and have provided a valid reference for successive comparisons and design verifications. Ultimately, it is suggested that some structural difficulties in managing the complexity of contemporary public open spaces can be better addressed via the synchronous layering of contributions from several disciplines. In particular, this article shows that it is possible to identify a limited number of significant variables (integration index, clustering coefficient, neighbourhood size, control, interaction index, gate count) suitable for describing the features that account for the liveliness of squares and hence the quality of their performance as public spaces. The reduction of the number of variables and the customisation of the analysis helped along the design workflow to focus on the most influent aspects of the project and thus helped to increase control over the design outcomes and to simplify the iterative evaluation process. Additionally, this work shows how to illustrate the effects that design actions are likely to produce in the public realm through a few maps that convey the main concepts of a configuration-informed design. The parametric logic adopted to generate the design elements seems to have responded well to the requirements of generality and adaptability of the method, and has effectively assisted in dealing with the complexity of the design tasks in terms of design efficiency. In fact, it allowed, at any stage of the design process, the introduction of a wider spectrum of inputs, thus the implementation of any kind of further analysis for evaluation purposes. The wider research project aims to provide a solid base to support design decision-making in urban design and planning practice and offer useful guidance for the development of individual projects such as streets, squares or parks. In the end, this article presents an evidence-based cross-disciplinary analysis and design method that may help understanding the dynamics and pitfalls of many traditional decision-making tools. The presented workflow prioritises the coherency of the design development process instead of adopting a final product approach. Specifically, the proposed inductive, data-driven design procedure is methodologically relevant because is eminently agnostic, local and based on the oucomes of a number of field observations.

To conclude, this study aims to use the issue of complexity in public open spaces as an opportunity to stimulate the development of new methodologies for the transformation, regeneration and re-invigoration of these shared meeting places. By enabling the simultaneous expression of features that give spaces their uniqueness, it proposed in a highly integrated design approach to iteratively evaluate the project and produce projections in order to achieve better informed proposals for a socio-spatial retrofit, which considers notions of comfort, security, equality, use and appropriation. Future research would encompass further testing of the method in other public open spaces, the use of data mining to disclose latent relations among the relevant parameters and the computational generation of a human scale design geometry, driven by "humanised" parameters.

\section{REFERENCES}

AHU, S.; CAGDAS, G.; SARIYLDIZ, S. A multidimensional exploration of urban attributes by data mining. In: INTERNATIONAL CONFERENCE ON COMPUTER AIDED ARCHITECTURAL DESIGN FUTURES, 14. 2011, Liège. Proceedings... Liège: Les Éditions de l'Université de Liège, 2011. p. 333-350.

ARCHITECTURAL DESIGN. Hoboken: Wiley, v. 85, n. 6 , nov./dez. 2015.
ASRIANA, N.; INDRAPRASTHA, A. Making sense of agent-based simulation. In: INTERNATIONAL CONFERENCE OF THE ASSOCIATION FOR COMPUTER-AIDED ARCHITECTURAL DESIGN RESEARCH IN ASIA, 21., 2016, Melbourne. Proceedings... Hong Kong: CAADRIA, 2016. p. 343-352.

BENEDIKT, M. L. To take hold of space: isovists and isovist fields. Environment and 
Planning B: Planning and Design, Thousand Oaks, v. 6, n. 1, p. 47-65, 1979.

CAN, L. et al. Morphological analysis of the transformations of Konak Square in Izmir. In: INTERNATIONAL SPACE SYNTAX SYMPOSIUM, 9., 2013, Seoul. Proceedings... Seoul: Sejong University, 2013. p. 39:1-39:15.

CHOAY, F. La città: utopie e realtà. 2. ed. Torino: Giulio Einaudi, 1973.

$\mathrm{CHOI}, \mathrm{A} .-\mathrm{S}$. et al. Application of the space syntax theory to quantitative street lighting design. Building and Environment, Amsterdam, v. 41, n. 3, p. 355-366, 2006.

CLOQUET, L. Traité d'architecture: éléments de l'architecture, types d'édifices, esthétique, composition et pratique de l'architecture. Paris: Baudry, 1898.

CULLEN, G. The concise townscape. London: Routledge; New York: The Architectural Press, 1961.

CUTINI, V. Configuration and centrality: some evidence from two Italian case studies. In: INTERNATIONAL SPACE SYNTAX SYMPOSIUM, 3., 2001, Atlanta. Proceedings... Atlanta: Georgia Institute of Technology, 2001. p. 32:1-32:11

Lines and squares: towards a configurational approach to the morphology of open spaces. In: INTERNATIONAL SPACE SYNTAX SYMPOSIUM, 4., 2003, London. Proceedings... London: University College London, 2003. p. 49:1-49:14.

DALTON, R. C. The secret is to follow your nose: route path selection and angularity. Environment and Behaviour, Thousand Oaks, v. 35, n. 1, p. 107-131, 2003.

DURSUN, P. Space syntax in architectural design. In: INTERNATIONAL SPACE SYNTAX SYMPOSIUM, 6., 2007, Istanbul. Proceedings... Istanbul: Istanbul Technical University Faculty of Architecture, 2007. p. $56: 1-56: 12$.

GEHL, J. Life between buildings: using public space. 6. ed. London: Island Press, 2011

GEHL, J.; SVARRE, B. How to study public life. London: Island Press, 2013.

GUERREIRO, M. R. P. et al. Networks and opportunistic urban design: a strategy for regeneration of public spaces in Lisbon. In: CAVALLO, R. et al. (Eds.). New urban configurations. Delft: TU Delft, 2014. p. 766-771.

GUIDONI, E. Storia dell'urbanistica. Laterza, 1989.

HEITOR, T. et al. Breaking of the medieval space: the emergence of a new city of enlightenment. In: INTERNATIONAL SPACE SYNTAX SYMPOSIUM, 2., 1999, Brasília, DF. Proceedings... Brasília, DF: Universidade de Brasília, 1999. v. 2, p. 55:1-55:14.

HILLIER, B. Space is the machine: a configurational theory of architecture. Cambridge, MA: Cambridge University Press, 1996

Spatial sustainability in cities organic patterns and sustainable forms. In: INTERNATIONAL SPACE SYNTAX SYMPOSIUM, 7., 2009, Stockholm. Proceedings... Stockholm: Royal Institute of Technology, 2009. p. K:01-K:20.

HILLIER, B.; HANSON, J. The social logic of space. Cambridge, MA: Cambridge University Press, 1984

HILLIER, B.; LIDA, S. Network and psychological effects in urban movement. In: INTERNATIONAL CONFERENCE ON SPATIAL INFORMATION THEORY, 7., 2005, Ellicottville. Spatial Information Theory. New York: Springer, 2005. p. 475-490.

HILLIER, B. et al. Natural movement: or, configuration and attraction in urban pedestrian movement. Environment and Planning B: Planning and Design, Thousand Oaks, v. 20, n. 1, p. 29-66, 1993.

JACOBS, J. The death and life of great american cities. New York: Random House, 1961.

KARIMI, K. A configurational approach to analytical urban design: space syntax methodology. Urban Design International, New York, v. 17, n. 4, p. 297-318, 2012.

KOOHSARI, M. J. et al. Using space syntax to assess the built environment for physical activity: applications to research on parks and public open spaces. Leisure Sciences: an interdisciplinary journal, Abingdon, v. 36, n. 2, p. 206-216, 2014.

KRIER, R. Urban space: Stadtraum. 3. ed. London: Academy, 1979.

KUBAT, A. S. et al. Evaluating the impacts of an urban design project: multiphase analyses of Taksim Square and Gezi Park. In: INTERNATIONAL SPACE SYNTAX SYMPOSIUM, 10., 2015, London. Proceedings... London: University College London, 2015. p. 73:1-73:17.

LAWSON, B. How designers think: the design process demystified. 3. ed. New York: The Architectural Press, 2003.

LOPES, J. V. et al. Multidimensional analysis of public open spaces: urban morphology, parametric modelling and data mining. In: EDUCATION AND RESEARCH IN COMPUTER AIDED ARCHITECTURAL 
DESIGN IN EUROPE, 33., 2015, Vienna. Proceedings... Vienna: Vienna University of Technology, 2015. v. 1, p. 351-360.

LOPES, J. V. et al. Multidimensional study of urban squares through perimetral analysis: Three Portuguese case studies. In: INTERNATIONAL SPACE SYNTAX SYMPOSIUM, 11., 2017, Lisbon. Proceedings... Lisbon: Instituto Superior Técnico, 2017. p. 85:1-85:20.

$\mathrm{LYNCH}, \mathrm{K}$. The image of the city Cambridge, MA: The MIT Press, 1960

MADANIPOUR, A. Why are the design and development of public spaces significant for cities? Environment and Planning B Planning and Design, Thousand Oaks, v. 26, n. 6, p. 879-891, 1999

MICHEL, R. (Ed.). Design research now: essays and selected projects. Basel: Birkhäuser, 2007.

MOTTA, E. Reusable components for knowledge modelling: case studies in parametric design problem solving Amsterdam: IOS, 1999.

NISHA, B.; NELSON, M. Making a case for evidence-informed decision making for participatory urban design. Urban Design International, New York, v. 17, n. 4 , p. 336-348, 2012.

PAIO, A. et al. Urban squares morphologies: contributions of a multidimensional analysis. In: NEXUS 2016: ARCHITECTURE AND MATHEMATICS CONFERENCE, 11., 2016, San Sebastián. Proceedings... Turin: KWB, 2016. p. 113-118.

PENN, A.; TURNER, A. Space syntax based agent simulation. In: INTERNATIONAL
CONFERENCE ON PEDESTRIAN AND EVACUATION DYNAMICS, 1., 2001, Duisburg. Proceedings... London: University College London, 2001. p. 99-114.

PEZZICA C.; PAIO A.; LOPES J. V. Square design: from digital analysis to urban design. In: INTERNATIONAL CONFERENCE OF IBERO-AMERICAN DIGITAL GRAPHIC SOCIETY, 20., 2016, Buenos Aires. Proceedings... Buenos Aires: University of Buenos Aires, 2016. p. 86-93.

SEARGENT, J. A.; NIEMASZ, J.; REINHART, C. F. Shaderade: combining rhinoceros and energy plus for the design of static exterior shading devices. In: INTERNATIONAL CONFERENCE OF INTERNATIONAL BUILDING PERFORMANCE SIMULATION ASSOCIATION, 12., 2011, Sydney. Proceedings... Abingdon: Taylor \& Francis, 2011. p. 310-317.

SITTE, C. L’arte di costruire le città. Milano: Antonio Vallardi, 1953.

SPACE SYNTAX. Nottingham Old Market Square: site analysis and public realm design input. London: Space Syntax, 2004.

TURNER, A. et al. From isovists to visibility graphs: a methodology for the analysis of architectural space. Environment and Planning B: Planning and Design, Thousand Oaks, v. 28, n. 1, p. 103-121, 2001.

WHYTE, W. H. The social life of small urban spaces. New York: Project for Public Spaces, 2001.

ZUCKER, P. Town and square: from the agora to the village green. New York, Columbia University Press, 1959.
Camilla Pezzica

PezzicaC@cardiff.ac.uk

João Ventura Lopes

jvsls@iscte.pt

Alexandra Claudia Rebelo Paio alexandra.paio@iscte.pt 
